\title{
APLIKASI SENSOR CAHAYA UNTUK ALARM ANTI PENCURI
}

Asita Shoman Muzaki, Arief Hendra, Wahyu Pamungkas

Akademi Teknik Telekomunikasi Sandhy Putra purwokerto

\begin{abstract}
ABSTRAK
Kasus pencurian di rumah kosong yang ditinggal pergi oleh pemiliknya belakangan ini marak terjadi. Berangkat dari pemikiran ini penulis mencoba merancang alarm yang dapat mendeteksi pergerakan seseorang saat rumah dalam kondisi kosong, ditinggalkan oleh pemiliknya. Alat ini mempunyai prinsip kerja yaitu mendeteksi bayangan seseorang yang melewati titik tertentu. Perancangan dan pembuatan perangkat ini menggunakan sensor cahaya berupa LASER dan LDR yang dirangkai dengan transistor sebagai saklar otomatis serta LED dan telepon rumah untuk melakukan panggilan kepada nomor telepon pemilik rumah. Komponen yang dipakai dalam pembuatan perangkat ini antara lain IC LM7805, LASER pointer, resistor, transistor BC108, LED, relay dan telepon rumah. Perancangan dan pembuatan alat menggunakan software multisim 10.1 sebagai simulator rangkaian, dan software eagle 5.1.1 untuk mendesain jalur rangkaian pada papan PCB. Saat cahaya LASER tidak sampai ke LDR karena terhalang oleh sesuatu, maka rangkaian output yang berupa indikator LED dan panggilan dari telepon rumah akan aktif.
\end{abstract}

Kata kunci: alarm, sensor cahaya, saklar otomatis, relay.

\section{PENDAHULUAN}

Tingkat penganguran yang tinggi mengakibatkan tindak kejahatan semakin meningkat, khususnya tindakan pencurian atau perampokan yang dilakukan di perumahan atau perkantoran yang ditinggal oleh pemiliknya.

Pengamanan yang dilakukan dengan memberikan pengamanan yang konvensional yaitu dengan brankas ternyata masih menimbulkan persoalan ketika pencuri berusaha membawa lari brankas. Dari kejadian tersebut dirumuskan permasalahan yaitu bagaimana melakukan pengamanan terhadap barang-barang berharga dan dapat mengetahui bila ada orang yang masuk di wilayah rumah tanpa sepengetahuan pemilik rumah.

Tujuan yang hendak dicapai dalam penelitian ini adalah menciptakan suatu sistem alarm yang memberikan tanda bila ada orang yang mulai memasuki wilayah rumah dengan bantuan sensor cahaya.

\subsection{Telepon Rumah}

Mempunyai beberapa komponen utama, antara lain:

a. Microphone dan Speaker

Microphone berfungsi untuk mengubah sinyal suara menjadi sinyal listrik yang berfluktuasi sesuai gelombang suara aslinya. Sedangkan speaker berfungsi sebagai pengubah sinyal listrik menjadi gelombang suara.

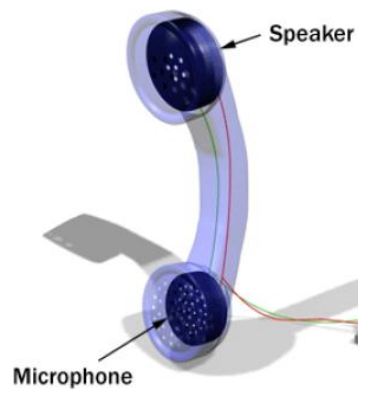

Gambar 1. Microphone dan Speaker

b. Hook Switch

Hook Switch berfungsi untuk menghubungkan (connects) dan memutuskan (disconnects) telepon dari jaringan telepon. Hook switch ini terletak pada tempat gagang telepon, sehingga jaringan hanya terhubung jika telepon diangkat. 
c. Keypad

Keypad terdiri dari bermacam-macam tombol. Digitnya terdiri dari digit 0-9 serta digit * dan \#.

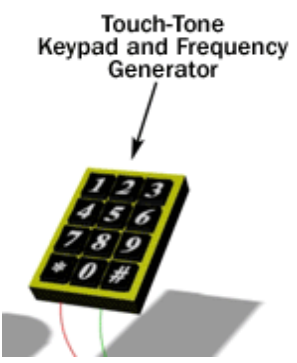

Gambar 2. Keypad

\section{d. Ringer}

Ringer merupakan sebuah bel yang berdering untuk mengindikasikan bila ada panggilan telepon.

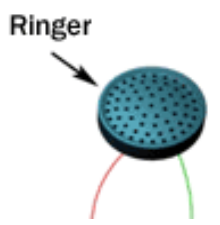

Gambar 3. Ringer

\subsection{Light Amplification by Stimulated Emission of Radiation (LASER)}

Sumber cahaya umum, seperti bola lampu incandescent, memancarkan foton hampir ke seluruh arah, biasanya melewati spektrum elektromagnetik dari panjang gelombang yang luas, laser biasanya memancarkan foton dalam cahaya yang sempit sehingga sinar laser dapat terfokus pada satu titik.

Konstruksi dari sebuah laser dapat dilihat pada gambar:

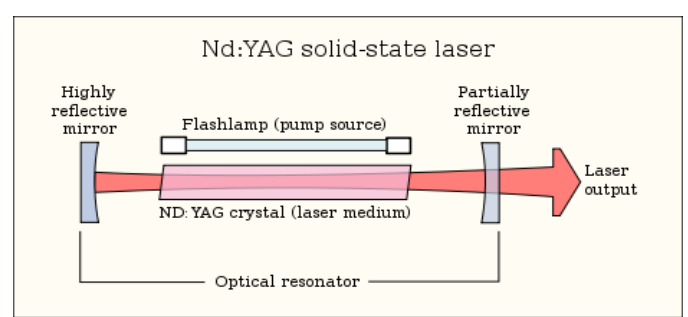

Gambar 4.Konstruksi Laser

Pump source adalah bagian yang menghasilkan energi kepada sistem laser (sebagai pembangkit). Laser medium adalah bagian yang menentukan operasi panjang gelombang dari sebuah laser.

Optical resonator dalam bentuk paling sederhana adalah dua buah cermin yang mempunyai tingkat refleksi yang berbeda. Cermin dengan tingkat refleksi yang tinggi ditempatkan di bagian belakang dari laser medium, sedangkan cermin dengan tingkat refleksi rendah akan ditempakan membelakangi output laser (sebagai output coupler).

\subsection{Light Emitting Diode (LED)}

LED terbuat dari berbagai material setengah penghantar campuran seperti misalnya gallium arsenida fosfida (GaAsP), gallium fosfida $(\mathrm{GaP})$, dan gallium aluminium arsenida (GaAsP). Karakteristik LED yaitu jika diberi forward bias, maka pertemuan arus akan mengeluarkan cahaya dan warna cahaya bergantung pada jenis dan kadar material pertemuan. Ketandasan cahaya berbanding lurus dengan arus maju yang mengalirinya. Dalam kondisi menghantar, tegangan maju pada LED merah adalah 1,6 sampai 2,2 volt, LED kuning 2,4 volt, LED hijau 2,7 volt. Sedangkan tegangan terbaik maksimum yang 
diperbolehkan pada LED merah adalah 3 volt, LED kuning 5 volt, LED hijau 5 volt.

\subsection{Diode proteksi}

Sinyal diode biasanya juga digunakan untuk melindungi transistor dan IC dari tegangan ringkas yang dihasilkan ketika sebuah Relay coil dimatikan. Gambar di bawah memperlihatkan bagaimana sebuah protection diode dihubungkan dengan Relay coil.

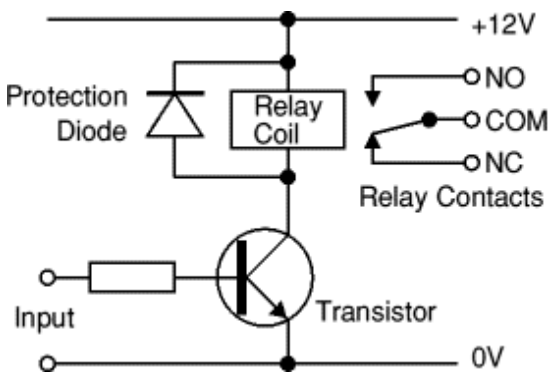

Gambar 5. Pengaplikasian Diode Proteksi

Protection diode mengijinkan tegangan listrik untuk mengarahkan satu arus ringkas melalui coil (dan diode) sehingga medan magnet menghilang dengan cepat dibandingkan dengan tanpa dioda. Hal ini mencegah tegangan listrik terimbas menjadi cukup tinggi untuk menyebabkan kerusakan terhadap transistor dan IC

\subsection{Light Dependent Resistor (LDR)}

LDR dibuat dari bahan semikonduktor beresistansi tinggi yang tidak dilindungi dari cahaya. Jika cahaya yang mengenainya memiliki frekuensi yang cukup tinggi, foton yang diserap oleh semikonduktor akan menyebabkan elektron memiliki energi yang cukup untuk meloncat ke pita konduksi. Elektron bebas yang dihasilkan akan mengalirkan listrik, sehingga menurunkan resistansinya.

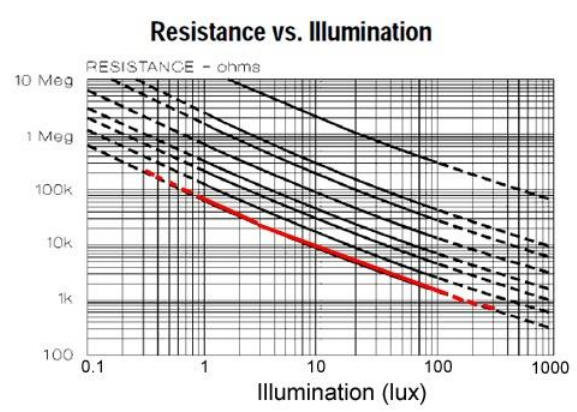

Gambar 6. Grafik Perbandingan Antara Resistansi LDR dengan Kadar Cahaya ${ }^{[15]}$

Dari gambar di atas, dapat diketahui bahwa semakin terang pencahayaaan yang mengenai LDR, maka resistansinya akan semakin mengecil. Jadi, resistansi LDR berbanding terbalik dengan iluminasi/ kadar cahaya yang mengenainya.

\subsection{Relay}

Relay adalah saklar yang dioperasikan secara elektrik. Arus yang mengalir melalui kumparan relay menciptakan medan magnet yang menarik tuas dan merubah kontak saklar. Arus kumparan dapat di-“on" atau “off'-kan sehingga relay memiliki dua posisi saklar.

Ada beberapa jenis relay antara lain:

a. Single Pole Single Throw (SPST) mempunyai satu kutub (common) dan satu kaki sebagai output dari relay (single switch).

b. Single Pole Double Throw (SPDT) mempunyai satu kutub (common) dan dua kaki sebagai output relay (double switches).

c. Double Pole Single Throw (DPST) mempunyai dua kutub (common) dan masing-masing satu kaki sebagai output relay (single switch). 


\section{d. Double Pole Double Throw (DPDT)} mempunyai dua kutub (common) dan masing-masing dua kaki sebagai output relay (double switches).

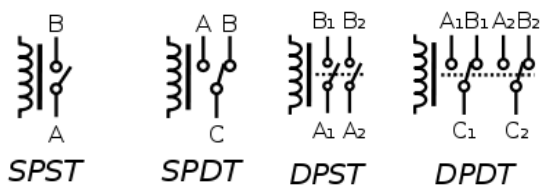

Gambar 7. Jenis-jenis Relay

\subsection{Voltage Divider Transistor}

Untuk dapat mengoperasikan transistor, diperlukan rangkaian pembiasan. Bias bagi tegangan digunakan dalam perangkatuntuk membandingkan 2 buah resistor basis yang kemudian dapat diatur sesuai kebutuhan. Dengan asumsi nilai $\mathrm{V}_{\mathrm{BE}}=0,7 \mathrm{~V}$ (silicone transistor), maka titik operasi (Q) dapat dihitung:

$$
\begin{aligned}
& R_{B}=\frac{R_{1} \cdot R_{2}}{R_{1}+R_{2}} \\
& V_{B B}=\frac{R_{2}}{R_{1}+R_{2}} \cdot V_{C C} \\
& I_{B Q}=\frac{V_{B B}-V_{B E}}{R_{B}+\left(\beta_{D C}+1\right) \cdot R_{E}} \\
& I_{C Q}=\beta_{D C} \cdot I_{B Q} \\
& V_{C E Q}=V_{C C}-I_{C Q} \cdot\left(R_{C}+R_{E}\right)
\end{aligned}
$$

Nilai maksimal dari arus dan tegangan dapat ditentukan dengan persamaan garis beban, dan dapat dibentuk dalam diagram berikut:

$$
\begin{aligned}
& I_{C}=0 \rightarrow V_{C C}=V_{C E} \\
& V_{C E}=0 \rightarrow V_{C C}=I_{C} \cdot\left(R_{C}+R_{E}\right) \rightarrow I_{C}= \\
& \frac{V_{C C}}{R_{C}+R_{E}}
\end{aligned}
$$

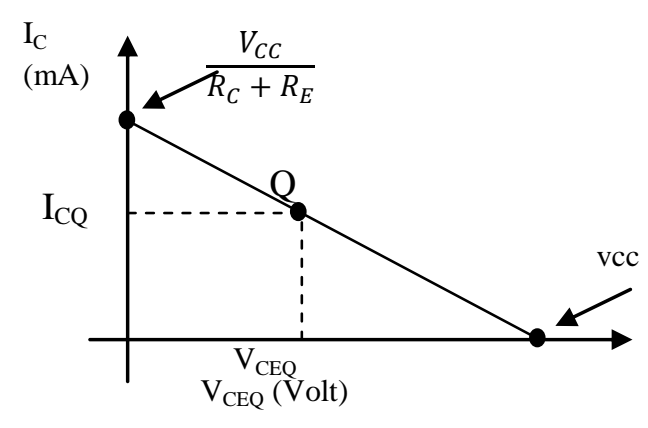

Gambar 8. Garis Beban DC Untuk Rangkaian Bias Pembagi Tegangan

\section{METODOLOGI PENELITIAN}

Dalam pembuatan perangkat ini, jenis metode penelitian yang digunakan adalah eksperimental. Metode ini dilakkukan guna mendapatkan rancangan alat dengan cara mencari, memodifikasi dan menguji rangkaianrangkaian elektronika di dalam beberapa blok berbeda, yang kemudian disatukan menjadi suatu perangkat lengkap.

\subsection{Peracangan Sistem}

Secara umum, konfigurasi alarm dengan sistem kerja saklar otomatis terdiri dari input, pensaklaran otomatis, dan output. Dalam perancangan dan pembuatan alat ini, diperlukan beberapa komponen utama, antara lain LASER dan LDR sebagai input, transistor sebagai saklar otomatis, dan relay yang berfungsi untuk menghubungkan rangkaian keluaran dengan telepon rumah yang sudah disiapkan.

Bentuk blok diagram alarm anti pencuri dapat dilihat pada Gambar 11 di bawah: 


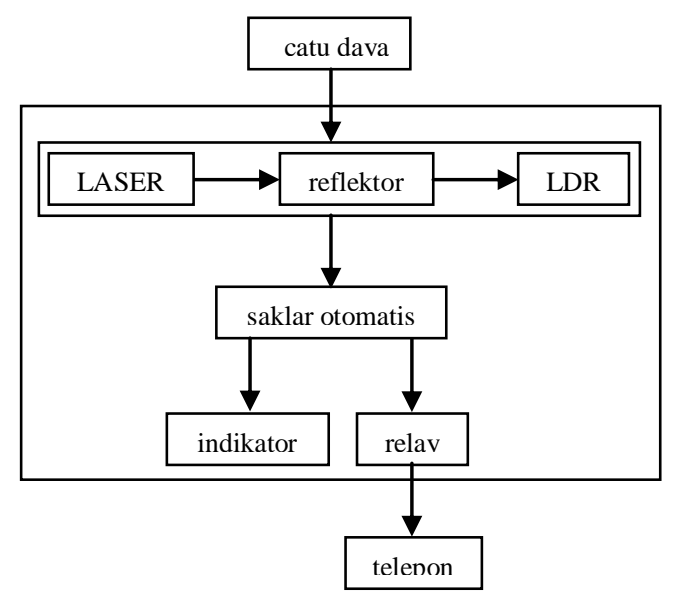

Gambar 9. Blok Diagram Alat

Input dari rangkaian terdiri dari reflektor berupa cermin untuk memantulkan sinar yang dihasilkan oleh LASER dan LDR sebagai sensor yang mengawasi keberadaan sinar LASER. Saklar otomatis akan memutus dan menyambungkan aliran arus pada kondisi tertentu. Output dari rangkaian yang dibuat terdiri dari indikator berupa LED dan sambungan ke relay yang berfungsi untuk mengaktifkan tombol redial pada pesawat telepon.

\subsection{Perancangan Rangkaian}

\subsubsection{Rangkaian Catu Daya}

Rangkaian catu daya ini digunakan untuk memberikan tegangan masukan sebesar 5 volt pada rangkaian alat. Rangkaian catu daya ini terdiri dari beberapa blok rangkaian antara lain:

\section{a. Transformator}

Transformator yang dipakai adalah jenis transformator step down. Tegangan masukan dari PLN sebesar $220 \mathrm{~V}$ diturunkan menjadi $12 \mathrm{~V}$ dengan nilai arus $1 \mathrm{~A}$. Tegangan puncak pada transformator dapat dihitung dengan persamaan:

$$
V_{P}=\frac{V_{r m s}}{0,707}
$$

Jadi,

$$
V_{P}=\frac{12}{0,707}=16,97 \mathrm{~V}
$$

b. Penyearah (rectifier)

Penyearah yang digunakan adalah jenis penyearah jembatan yang terdiri dari empat buah dioda. Arus bolak-balik (AC) dari transformator diubah menjadi arus searah (DC) untuk mencatu IC regulator. Besar tegangan DC yang dihasilkan oleh penyearah ini yaitu sebesar:

$$
V_{D C}=\frac{2 V_{P}}{\pi}
$$

Jadi,

$$
V_{D C}=\frac{2 \times 16,97}{\pi}=10,81 \mathrm{~V}
$$

c. Filter (smoothing)

Filter terdiri dari kapasitor polar yang disusun paralel dengan output dari penyearah jembatan. Efek arus AC yang masih ada pada arus DC konstan diminimalkan sehingga tegangan ripple akan berkurang. Semakin besar nilai kapasitor yang digunakan, maka akan semakin mengurangi tegangan ripple.

$$
V_{\text {rip }}=\frac{I}{f C}
$$

Dengan:

$$
\begin{aligned}
& f=2 f_{\text {in }}=2 \times 60 \mathrm{~Hz}=120 \mathrm{~Hz} \\
& \mathrm{C}=220 \mu \mathrm{F}
\end{aligned}
$$

Jadi,

$$
V_{\text {rip }}=\frac{1}{120 \times 0,22}=0,038 \mathrm{~V}
$$

\section{d. Regulator}

Voltage regulator berfungsi untuk menstabilkan tegangan keluaran dari penyearah. Regulator yang digunakan adalah IC jenis LM7805 yang berfungsi untuk 
menghasilkan tegangan keluaran sebesar 5 volt.

Dari perhitungan di sisi output dari penyearah tegangan dihasilkan tegangan keluaran sebesar 10,81 volt. tegangan ini adalah tegangan masukan yang mencatu IC LM7805. Dari datasheet IC LM7805, diketahui tegangan input yang diperbolehkan untuk mencatu IC yaitu antara 7 volt - 20 volt, dan akan menghasilkan tegangan output sebesar 4,80 volt $-5,20$ volt.

Berikut ini merupakan gambar rangkaian catu daya yang digunakan pada alat:

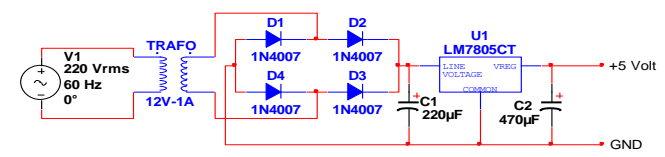

Gambar 10. Rangkaian Catu Daya Alarm

\subsubsection{Rangkaian Sensor (sensor part)}

Berikut ini gambar rangkaian penyala laser dan rangkaian pengindikasi:

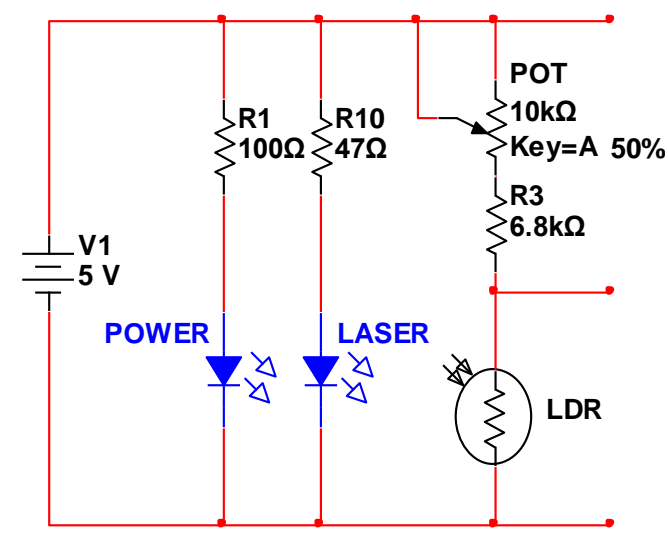

Gambar 11. Rangkaian Sensor (Sensor Part)

Pada rangkaian penyala LASER dipasang resistor seri $47 \Omega$ guna membatasi arus yang mencatu LASER sehingga perangkat LASER tidak mudah rusak.
Berikut ini adalah perhitungan mencari besar nilai resistor seri pada rangkaian LASER:

Diketahui:

$\mathrm{V}_{\text {in }}=$ Tegangan sumber $(5 \mathrm{~V})$

$\mathrm{V}_{\text {LASER }}=$ Tegangan LASER diberikan $2 \mathrm{~V}$ (maksimal dari datasheet 2,7 V)

$\mathrm{I}=$ Arus yang melewati LASER (typical dari datasheet $55 \mathrm{~mA}$ )

Sehingga,

$$
\begin{array}{r}
\quad V_{\text {in }}=V_{R}+V_{\text {LASER }} \\
5 \mathrm{~V}=R_{S} \cdot I+2 \mathrm{~V} \\
\rightarrow \quad R_{S} \cdot I=3 \mathrm{~V}
\end{array}
$$

Maka,

$$
R_{S}=\frac{3 V}{0,055 \mathrm{~A}}=54,545 \Omega
$$

Pada rangkaian pengindikasi, diberikan potensiometer $10 \mathrm{~K} \Omega$ yang berfungsi untuk membatasi arus yang melewati rangkaian, dan juga dimanfaatkan untuk mengatur sensitifitas LDR. Semakin kecil harga potensiometer, maka nilai sensitifitas LDR akan semakin tinggi. Artinya, nilai tahanan LDR yang dibutuhkan untuk mengaktifkan output akan semakin kecil.

\subsubsection{Rangkaian Transistor}

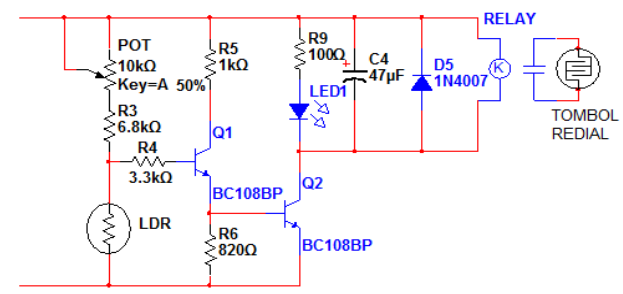

Gambar 12. Rangkaian Saklar Otomatis

Dalam gambar, ada 2 buah transistor dengan rangkaian darlington transistor yang berfungsi untuk menaikkan arus.

Rangkaian ekuivalen transistor Q1: 


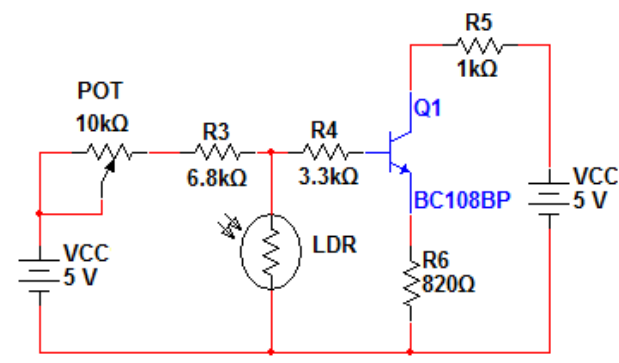

Gambar 13. Rangkaian Ekuivalen Transistor Q1

Berdasarkan gambar di atas, RB dan VBB dapat diperoleh:

$$
\begin{gathered}
R B=((P O T+R 3) / / L D R)+R 4 \\
V B B=\frac{L D R}{P O T+R 3+L D R} \cdot V C C
\end{gathered}
$$

Dengan:

$$
\begin{aligned}
& \mathrm{RB}=\text { Tahanan Basis }(\Omega) \\
& \mathrm{RC}=\text { Tahanan Kolektor }(\Omega) \\
& \mathrm{RE}=\text { Tahanan Emitor }(\Omega)
\end{aligned}
$$$$
\text { POT = Tahanan Potensiometer (akan }
$$
diset dalam tiga kondisi yaitu saat bernilai $1 \mathrm{~K} \Omega, 5 \mathrm{~K} \Omega$ dan $10 \mathrm{~K} \Omega$ )

LDR = Tahanan LDR (ada dua kondisi, yaitu saat keadaan gelap, bernilai $>2 \mathrm{M} \Omega$ dan saat keadaan terang, bernilai $<1 \mathrm{~K} \Omega$ )

$\mathrm{VBB}=$ Tegangan Basis

$\mathrm{VCE}=$ Tegangan Kolektor-Emitor

VCC $=$ Tegangan Sumber $(5$ volt $)$

$\mathrm{VBE}=$ Tegangan Basis-Emitor ( 0,7 volt $)$

Tabel 1. Perhitungan Transistor Q1 Saat

Kondisi Gelap (LDR $>2 \mathrm{M} \Omega$ )

\begin{tabular}{|c|c|c|c|c|c|}
\hline $\mathrm{POT}$ & $\mathrm{RB}$ & $\mathrm{VBB}$ & $\mathrm{I}_{\mathrm{BQ} 1}$ & $\mathrm{I}_{\mathrm{CQ} 1}$ & $\mathrm{VCEQ} 1$ \\
$(\Omega)$ & $(\Omega)$ & $(\mathrm{V})$ & $(\mu \mathrm{A})$ & $(\mathrm{mA})$ & $(\mathrm{V})$ \\
\hline $1 \mathrm{~K}$ & $11 \mathrm{~K}$ & 4,98 & $45,6194,562$ & $-3,303$ \\
\hline $5 \mathrm{~K}$ & $15 \mathrm{~K}$ & 4,97 & $43,6524,365$ & $-2,945$ \\
\hline $10 \mathrm{~K}$ & $20 \mathrm{~K}$ & $4,95841,4124,141$ & $-2,537$ \\
\hline
\end{tabular}

Tabel 2. Perhitungan Transistor Q1 Saat

Kondisi Terang $(\mathrm{LDR}<1 \mathrm{~K} \Omega)$

\begin{tabular}{|c|c|c|c|c|c|}
\hline $\begin{array}{c}\text { POT } \\
(\Omega)\end{array}$ & $\mathrm{RB}(\Omega)$ & $\begin{array}{c}\mathrm{VBB} \\
(\mathrm{V})\end{array}$ & $\begin{array}{c}\mathrm{I}_{\mathrm{BQ} 1} \\
(\mu \mathrm{A})\end{array}$ & $\begin{array}{c}\mathrm{I}_{\mathrm{CQ} 1} \\
(\mathrm{~mA})\end{array}$ & $\begin{array}{c}\mathrm{VCEQ} 1 \\
(\mathrm{~V})\end{array}$ \\
\hline $1 \mathrm{~K}$ & 418,364 & 0,568 & $-1,517$ & $-0,152$ & 5,276 \\
\hline $5 \mathrm{~K}$ & 4221,875 & 0,391 & $-3,554$ & $-0,355$ & 5,647 \\
\hline $10 \mathrm{~K}$ & 4243,82 & 0,281 & $-4,814$ & $-0,481$ & 5,876 \\
\hline
\end{tabular}

Arus kolektor dari transistor Q2 dicari dengan persamaan:

$$
I C_{Q 2}=I E_{Q 1} \cdot \beta_{D C}
$$

Dengan:

$$
\begin{aligned}
\mathrm{I}_{\mathrm{EQ} 1}= & \mathrm{I}_{\mathrm{BQ} 2} \\
= & \text { Arus yang melewati basis transistor } \\
& \mathrm{Q} 2 \text { (diasumsikan sama dengan nilai } \\
& \left.\mathrm{I}_{\mathrm{CQ} 1}\right)(\mathrm{mA})
\end{aligned}
$$

$\mathrm{I}_{\mathrm{CQ} 2}=$ Arus yang melewati kolektor $(\mathrm{A})$

Tabel 3. Perhitungan Transistor Q2 Saat Kondisi Gelap (LDR > 2M $\Omega$ )

\begin{tabular}{|c|c|c|}
\hline $\operatorname{POT}(\Omega)$ & $\mathrm{I}_{\mathrm{BQ} 2}(\mathrm{~mA})$ & $\mathrm{I}_{\mathrm{CQ} 2}(\mathrm{~A})$ \\
\hline $1 \mathrm{~K}$ & 4,562 & 0,456 \\
\hline $5 \mathrm{~K}$ & 4,365 & 0,436 \\
\hline $10 \mathrm{~K}$ & 4,141 & 0,414 \\
\hline
\end{tabular}

Tabel 4. Perhitungan Transistor Q2 Saat Kondisi Terang $(\mathrm{LDR}>1 \mathrm{~K} \Omega)$

\begin{tabular}{|c|c|c|}
\hline $\operatorname{POT}(\Omega)$ & $\mathrm{I}_{\mathrm{BQ} 2}(\mathrm{~mA})$ & $\mathrm{I}_{\mathrm{CQ} 2}(\mathrm{~A})$ \\
\hline $1 \mathrm{~K}$ & $-0,152$ & $-0,015$ \\
\hline $5 \mathrm{~K}$ & $-0,355$ & $-0,035$ \\
\hline $10 \mathrm{~K}$ & $-0,581$ & $-0,058$ \\
\hline
\end{tabular}

\subsubsection{Rangkaian Output}

Output rangkaian berupa LED dan relay dengan tegangan masukan 5 volt. Rangkaian LED diparalel dengan relay, bertujuan agar keduanya dapat aktif secara bersamaan. 


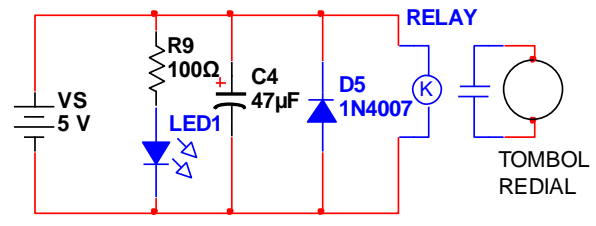

Gambar 14. Rangkaian Output

Pada rangkaian relay diparalel dengan kapasitor $47 \mu \mathrm{F}$ untuk menghilangkan bouncing ${ }^{[14]}$ dan dioda proteksi yang berfungsi untuk melindungi komponen lain dari medan magnet yang jatuh secara tiba-tiba.

\subsubsection{Perancangan Auto Dial}

Pada output relay disambungkan kabel jumper yang akan dihubungkan dengan slot redial pada pesawat telepon. Berikut merupakan gambar pemasangan auto dial yang terhubung dengan rangkaian:

a.
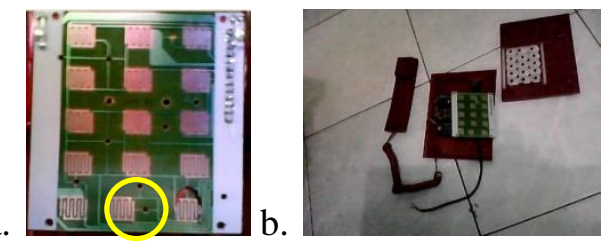

Gambar 15. Koneksi Auto Dial Pada Pesawat Telepon. a. Koneksi Kabel Ke Slot Redial b. Rangkaian Auto Dial

\section{HASIL DAN PEMBAHASAN}

\subsection{Pengujian Rangkaian}

Pengujian ini dilaksanakan untuk mengetahui kehandalan dari sistem dan untuk mengetahui apakah sudah sesuai dengan perencanaan atau belum.

Presentase kesalahan antara hasil perhitungan dengan hasil pengukuran dapat dicari dengan menggunakan rumus:

$$
\text { Error }=\left|\frac{n s-n p}{n s}\right| \cdot 100 \%
$$

Dengan:

Error $=$ Persentase kesalahan yang terjadi $(\%)$ ns $=$ Hasil perhitungan

$\mathrm{np}=$ Hasil pengukuran

\subsubsection{Pengujian Rangkaian Catu Daya}

Pengujian catu daya bertujuan untuk mengukur nilai tegangan keluaran trafo, penyearah jembatan, dan tegangan keluaran dari regulator.

Tabel 5. Hasil Uji Rangkaian Catu Daya

\begin{tabular}{|c|c|c|c|c|c|c|c|c|}
\hline \multicolumn{3}{|c|}{ Perhitungan } & \multicolumn{3}{|c|}{ Pengukuran } & \multicolumn{3}{|c|}{ Error (\%) } \\
\hline $\begin{array}{l}V_{P} \\
(V)\end{array}$ & $\begin{array}{l}\mathrm{V}_{\text {rectifie }} \\
\mathrm{r}(\mathrm{V})\end{array}$ & $\begin{array}{c}\mathrm{V}_{\mathrm{re}} \\
\mathrm{g} \\
\mathrm{V}\end{array}$ & $\begin{array}{l}\mathrm{V}_{\mathrm{P}} \\
(\mathrm{V})\end{array}$ & $\begin{array}{l}V_{\text {rectifie }} \\
r(V)\end{array}$ & $\mid \begin{array}{l}\mathrm{V}_{\text {reg }} \\
(\mathrm{V})\end{array}$ & $\mathrm{V}_{\mathrm{P}}$ & $V_{\text {rectifie }}$ & \\
\hline $\begin{array}{c}16,9 \\
7\end{array}$ & 10,81 & 5 & $\begin{array}{c}14,6 \\
5\end{array}$ & 11,24 & $\begin{array}{c}5,1 \\
1\end{array}$ & $\begin{array}{c}13,67 \\
1\end{array}$ & 3,978 & 2,2 \\
\hline
\end{tabular}

\subsubsection{Pengujian Rangkaian Transistor}

Pengujian ini dilakukan untuk mengetahui nilai arus basis pada rangkaian transistor Q1 (input) dan arus kolektor pada transistor Q2 (output).

Tabel 6. Hasil Uji Rangkaian Transistor

\begin{tabular}{|c|c|c|c|c|c|c|c|c|c|}
\hline \multirow[b]{2}{*}{ Kondisi } & \multicolumn{3}{|c|}{ Perhitungan } & \multicolumn{3}{|c|}{ Pengukuran } & \multicolumn{3}{|c|}{ Error (\%) } \\
\hline & $\begin{array}{l}\mathrm{POT} \\
(\mathrm{K} \Omega)\end{array}$ & $\begin{array}{l}\mathrm{Ib}_{\mathrm{Q} 1} \\
(\mu \mathrm{A})\end{array}$ & $\begin{array}{c}\mathrm{Ic}_{\mathrm{Q} 2} \\
(\mathrm{~A})\end{array}$ & $\begin{array}{l}\text { POT } \\
(\mathrm{K} \Omega)\end{array}$ & $\begin{array}{l}\mathrm{Ib}_{\mathrm{Q} 1} \\
(\mu \mathrm{A})\end{array}$ & $\begin{array}{l}\mathrm{Ic}_{\mathrm{Q} 2} \\
(\mathrm{~A})\end{array}$ & POT & $\mathrm{Ib}_{\mathrm{Q} 1}$ & $\mathrm{Ic}_{\mathrm{Q} 2}$ \\
\hline \multirow{3}{*}{ Gelap } & 1 & 45,619 & 0,456 & 1,01 & 39,2 & 0,4 & 1 & 14,07 & 14 \\
\hline & 5 & 43,652 & 0,436 & 4,94 & 39,1 & 0,4 & 1,2 & 10,428 & 8,257 \\
\hline & 10 & 41,412 & 0,414 & 10,28 & 38,2 & 0,4 & 2,8 & 7,756 & 3,382 \\
\hline \multirow{3}{*}{ Terang } & 1 & $-1,517$ & $\begin{array}{c}- \\
0,015\end{array}$ & 1,01 & $-1,7$ & $\begin{array}{c}- \\
0,02\end{array}$ & 1 & 12,063 & 33,333 \\
\hline & 5 & $-3,554$ & $\begin{array}{c}- \\
0,035\end{array}$ & 4,94 & -3 & $\begin{array}{c}- \\
0,03\end{array}$ & 1,2 & 15,588 & 14,286 \\
\hline & 10 & $-4,814$ & $\begin{array}{c}- \\
0,048\end{array}$ & 10,28 & -4 & $\begin{array}{c}- \\
0,04\end{array}$ & 2,8 & 16,909 & 16,667 \\
\hline
\end{tabular}

\subsubsection{Pengujian Rangkaian Input}

Pengujian ini dilakukan untuk mengetahui nilai-nilai arus dan tegangan pada LASER serta tahanan LDR saat kondisi terang dan gelap. 
Tabel 8. Hasil Uji Rangkaian Penyala LASER

\begin{tabular}{|c|c|c|c|c|c|}
\hline \multicolumn{2}{|c|}{ Perhitungan } & \multicolumn{2}{c|}{ Pengukuran } & \multicolumn{2}{c|}{ Error $(\%)$} \\
\hline $\begin{array}{c}\text { I }_{\text {LASER }} \\
(\mathrm{mA})\end{array}$ & $\begin{array}{c}\mathrm{V}_{\text {LASER }} \\
(\mathrm{V})\end{array}$ & $\begin{array}{c}\mathrm{I}_{\text {LASER }} \\
(\mathrm{mA})\end{array}$ & $\begin{array}{c}\mathrm{V}_{\text {LASER }} \\
(\mathrm{V})\end{array}$ & $\mathrm{I}_{\text {LASER }}$ & $\mathrm{V}_{\text {LASER }}$ \\
\hline 55 & 2 & 63,0 & 1,88 & 14,545 & $1 \%$ \\
\hline
\end{tabular}

Tabel 9. Hasil Uji Nilai Tahanan LDR

\begin{tabular}{|c|c|}
\hline Kondisi & $\begin{array}{c}\text { Tahanan } \\
\text { Terukur }(\Omega)\end{array}$ \\
\hline $\begin{array}{c}\text { Malam hari, terkena cahaya } \\
\text { bulan }\end{array}$ & $>2 \mathrm{M}$ \\
\hline Dalam ruangan, siang hari & $987 \mathrm{~K}$ \\
\hline Terang, terkena cahaya LASER & $30,4 \mathrm{~K}$ \\
\hline $\begin{array}{c}\text { Terang, tidak terkena matahari } \\
\text { langsung }\end{array}$ & $7,56 \mathrm{~K}$ \\
\hline $\begin{array}{c}\text { Terang, terkena cahaya } \\
\text { matahari langsung }\end{array}$ & $3,04 \mathrm{~K}$ \\
\hline
\end{tabular}

3.1.4. Pengujian Nilai Tahanan Input Minimal

Pengujian ini dilakukan untuk mengetahui nilai tahanan minimal yang dibutuhkan suatu LDR untuk dapat mengaktifkan output.

Tabel 10. Pengujian Nilai Tahanan Input

\begin{tabular}{|c|c|c|}
\hline $\begin{array}{c}\text { Nilai } \\
\text { Tahanan } \\
\text { POT }(\Omega)\end{array}$ & $\begin{array}{c}\text { Tahanan LDR } \\
(\Omega)\end{array}$ & Kondisi \\
\hline \multirow{2}{*}{$1 \mathrm{~K}$} & 0 & Mati \\
\cline { 2 - 3 } & $4,21 \mathrm{~K}$ & $\begin{array}{c}\text { Transisi dari } \\
\text { Mati ke Nyala }\end{array}$ \\
\cline { 2 - 3 } & $100 \mathrm{~K}$ & Nyala \\
\hline \multirow{2}{*}{$5 \mathrm{~K}$} & 0 & Mati \\
\cline { 2 - 3 } & $5,74 \mathrm{~K}$ & $\begin{array}{c}\text { Transisi dari } \\
\text { Mati ke Nyala }\end{array}$ \\
\cline { 2 - 3 } & $100 \mathrm{~K}$ & Nyala \\
\hline \multirow{2}{*}{$10 \mathrm{~K}$} & 0 & Mati \\
\cline { 2 - 3 } & $6,5 \mathrm{~K}$ & Transisi dari \\
\hline
\end{tabular}

\begin{tabular}{|c|c|c|}
\hline \multirow{2}{*}{$100 \mathrm{~K}$} & Mati ke Nyala \\
\cline { 2 - 3 } & Nyala \\
\hline
\end{tabular}

\subsection{Pengujian Sistem}

Pengujian sistem dilakukan untuk menguji apakah rangkaian sudah berjalan sesuai dengan sistem yang telah ditentukan.

Kondisi pertama yaitu saat alat dinyalakan dan sinar LASER langsung mengenai LDR tanpa ada halangan.

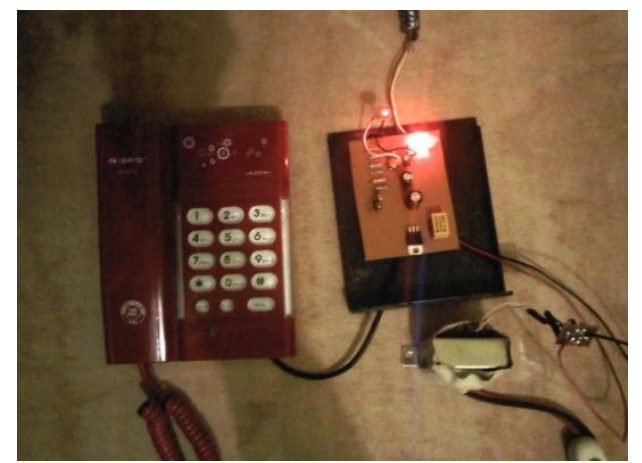

Gambar IV.8. Pengujian Sistem Saat Kondisi LDR Tekena Cahaya LASER

Kondisi Kedua yaitu saat alat dinyalakan dan sinar LASER tidak mengenai LDR karena terhalang oleh benda.

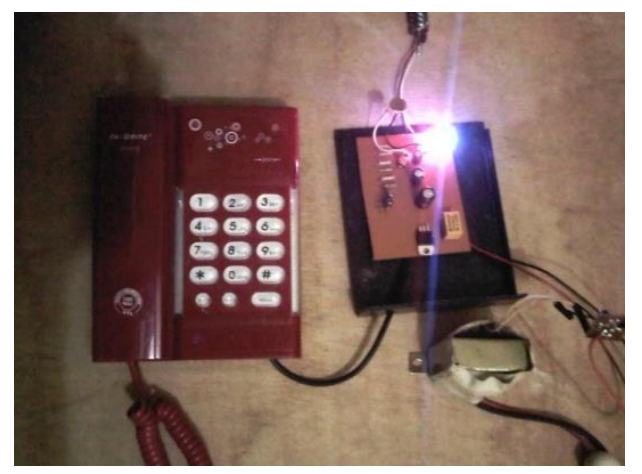

Gambar IV.9. Pengujian Sistem Saat Cahaya LASER Terhalang Oleh Benda

\section{KESIMPULAN}

1. Alarm anti pencuri dapat dibuat dengan menggunakan sinar LASER dan LDR sebagai sensor cahaya. 
2. Pada pengujian catu daya terjadi persentase error sebesar 13,671\%, $3,978 \%$, dan $2,2 \%$ yang disebabkan karena naik turunnya tegangan PLN.

3. Pada pengujian rangkaian transistor error terjadi karena nilai potensiometer dan nilai LDR yang tidak sama persis dengan saat pengukuran.

4. Pada pengujian rangkaian penyala LASER terjadi persentase error yang disebabkan karena nilai tahanan yang dibutuhkan yaitu sebesar 54,545 $\Omega$ tidak dapat ditemukan di pasaran, sehingga dipakai nilai tahanan yang mendekati hasil perhitungan yaitu sebesar $47 \Omega$.

5. Dari pengujian nilai tahanan input minimal dapat ditarik kesimpulan bahwa semakin besar nilai potensiometer yang digunakan, maka nilai tahanan minimal yang dibutuhkan untuk menyalakan output juga akan bertambah besar.

\section{DAFTAR PUSTAKA}

1. Anonymous. Diodes

http://www.kpsec.freeuk.com/components /diodes.htm

Diakses pada tanggal 13 Oktober 2010 pukul 15.00 wib

2. Anonymous. LED

http://www.kpsec.freeuk.com/components $\underline{\text { led.htm }}$

Diakses pada tanggal 13 Oktober 2010 pukul 15.00 wib

3. Anonymous. Relay

http://www.kpsec.freeuk.com/components /relay.htm
Diakses pada tanggal 13 Oktober 2010 pukul 15.00 wib

4. Anonymous. Sejarah Transistor http://www.unej.ac.id/fakultas/mipa/web_ fisika/webkuliah/diktatedas1/10sepuluh.p $\underline{\mathrm{df}}$

Diakses pada tanggal 13 Oktober 2010 pukul 15.00 wib

5. Anonymous. 2008. Percobaan 5 transistor sebagai saklar. Teknik Elektro STEI ITB. Bandung.

6. Arifin, Irwan. 2004. Elektronika I.

7. Diktat kuliah elektronika. 2009. AKATEL Sandhy Putra Purwokerto.

8. Malvino, Albert Paul. 2003. PrinsipPrinsip Elektronika. Jakarta: Salemba Teknika.

9. Prasetyono, Dwi Sunar. 2003. Belajar Sistim Cepat Elektronika. Yogyakarta: Absolut.

10. Suratman. 2001. Kamus Elektronika. Bandung: CV, Pustaka Grafika.

11. Wibawanto, Hari. 2007. Elektronika Dasar: Pengenalan Praktis. Semarang.

12. Yuliana, Mike. Pesawat Telepon https://lecturer.eeipsits.edu/ mieke/dasartelephony/toeri/t2pesawat\%20telepon.pdf Diakses pada tanggal 20 November 2010 pukul 16.00 wib

13. Zamidra Zam, Efvy. 2005. Panduan Praktis Belajar Elektronika. Surabaya: Indah. 